\title{
Effect of binary mixtures on chloride induced corrosion of rebars in concrete
}

\author{
A. Brenna, M. Ormellese, MP. Pedeferri and F. Bolzoni* \\ Politecnico di Milano, Dipartimento di Chimica, Materiali e Ingegneria Chimica "Giulio \\ Natta”Via Mancinelli 7, 20131 Milano, Italy \\ *E-mail:fabio.bolzoni@polimi.it
}

\begin{abstract}
Rebar corrosion is one of the most important phenomena affecting the durability of reinforced concrete structures. Corrosion inhibitors can be used as a preventative method, able to delay corrosion, or as repair method, to reduce corrosion rate. During more than 15 years in our laboratories an intense experimental research was carried out: the aim of the research was to identify new organic substances or mixtures thereof that might have inhibiting effectiveness. In the paper the effect of binary mixtures on chloride induced corrosion of rebars in concrete is studied; the mixtures are based on two amines, dimethylethanolamine (DMEA) and triethylenetetramine (TETA), and a carboxylate (benzoate); the tests were carried out for comparison purpose also in concrete containing nitrite, acknowledged to be the most effective product. The best results among the binary mixtures were shown by the benzoate-TETA, while the mixtures based on DMEA-TETA were not satisfactory. The performance of the mixtures is not comparable to nitrites.
\end{abstract}

Keywords: rebar corrosion, service life, chlorides, corrosion inhibitors, critical chloride content, organic mixtures.

Received: March 9, 2018. Published: March 20, 2018

doi: $\underline{10.17675 / 2305-6894-2018-7-2-3}$

\section{Introduction}

Corrosion of rebars occurs in carbonated or chloride contaminated concrete [1-4]. In the first case, the reaction with atmospheric $\mathrm{CO}_{2}$ lowers the concrete pore solution $\mathrm{pH}$, from typical values higher than 13 in pristine concrete to values lower than 9, provoking the dissolution of the passive film. In the second case, pitting corrosion occurs when the concentration of chlorides at the rebar surface is higher than a threshold value, which is mostly affected by $[1-8]$ :

- $\mathrm{pH}$ of concrete pore solution (type of cement)

- Electrochemical potential, as described also by the "Pedeferri Diagrams" for cathodic protection and prevention [5]

- Porosity at the interface concrete/steel. 
Even if the range of variation is quite high, the critical chloride content for carbon steel rebars is generally considered within the range $0.4-1 \% \mathrm{vs}$. mass of cement in aerated concrete [1].

Prevention of rebars corrosion in concrete is carried out by design and casting a concrete of suitable quality, with a low water/cement ratio, by performing a correct curing and casting, and by using an appropriate bar cover depth $[1,9,10]$. With regard to structures exposed to very corrosive environments, or for structures with a design life over 50 years, it could be appropriate to refer to additional protective methods: blended cements (especially in the case of chloride-induced corrosion), corrosion-resistant reinforcing steels, corrosion inhibitors, concrete coatings and cathodic protection $[1,9,10]$. Among these methods, corrosion inhibitors offer a simple solution, characterised by lower cost compared to other techniques, like stainless steel reinforcements or cathodic protection; on the other hand, effectiveness of corrosion inhibitors shall be well defined for a suitable use.

Corrosion inhibitors may be used as a corrosion-prevention method, when added directly to fresh concrete or as a restoration method for already corroded rebars (migrating inhibitors) $[1,11-32]$. In this paper only the use of corrosion inhibitors as a preventative method against chloride-induced corrosion is considered. Calcium nitrite based inhibitors are commercially available since years ' 70 [14-16]. They are internationally regarded as the most effective against corrosion: their inhibiting mechanism is well known, and the dosage is indicated in relation to the content of chlorides in the concrete: a minimum molar ratio nitrite to chloride is required, about 0.6 and ranging from 0.5 to 1 according to the literature $[1,11]$. Possible limitations of nitrites are related to their toxicity and to the possible leaching out in porous or cracked concrete over long service that could reduce the concentration below the minimum value: since their electrochemical mechanism is anodic oxidising, under-dosage could increase corrosion rate $[1,11]$. Other inorganic corrosion inhibitors as mono-fluoro-phosphate have been proposed as migrating inhibitors [17-19].

Organic commercial inhibitors, available since the $80^{\mathrm{s}}$ of the previous century, are mixtures of amines, alkanolamines and carboxylate compounds. Despite the fact that the active principles are known, their composition is patented and not defined: as a consequence, the dosage of inhibitor required to prevent corrosion in relation to the chloride content is not always provided [1,11]. Literature data record an increase in the critical chloride content up to a maximum $1.5 \%$ compared to the cement mass $[11,24,25]$.

The last 20 years have witnessed a growing interest in the study of new compounds capable of preventing or delaying corrosion. Studies have been conducted on noncommercial inhibitors, both inorganic (zinc oxide, molybdates, borates, stannanes, phosphates) and organic compounds (benzoate and its derivatives, carboxylate substances, quaternary ammonium salts, citrate and amine-based substances, ligninsulphonate, ...) $[11$, 33-54].

In this paper, corrosion of rebars in concrete subjected to accelerated chloride entry (i.e. ponding cycles), is studied; inhibitor mixtures based on 3 organic substances are considered: two amines, dimethylethanolamine (DMEA), triethylenetetramine (TETA), 
and one carboxylate, i.e. benzoate (Table 1). The organic substances have been selected during a prior research phase, during which 100 organic substances containing amino or carboxylic groups have been tested [55-57]. In a previous paper the results of tests carried out in concrete simulated pore solution have been presented [58]. In this paper, for comparison purposes, also nitrites are considered.

\section{Experimental}

Concrete have been manufactured with two water/cement ratios, 0.55 and 0.65 , and cement CEM II A/L 42.5R, according to EN 197 standard [59]. The mix design is reported in Table 2, together with some properties of fresh and hardened concrete. The experimental corrosion inhibitors were based on binary mixtures of three organic substances (Table 1); for comparison purposes, calcium nitrite was also tested. Organic substances were selected among the more performing in previous phase of the research [55-57]. The dosage of inhibitors $v s$. cement mass is reported in the following:

- nitrite $3 \%$ or $6 \%$

- mix TETA $(0.4 \%)+$ benzoate $(0.4 \%)$

- mix TETA $(0.8 \%)+$ benzoate $(0.8 \%)$

- mix DMEA $(0.3 \%)+$ TETA $(0.3 \%)$

- mix DMEA $(0.6 \%)+$ TETA $(0.6 \%)$

Inhibitors in the added dosage do not reduce significantly the mechanical properties nor the workability (Table 1).

For each combination of w/c ratio and inhibitor dosage, two specimens were cast. Every concrete specimen contains five carbon steel rebars, five mixed-MMO reference electrodes and 6 counter electrodes in stainless steel type AISI 304 for the measurements of linear polarisation resistance. Carbon steel rebars were in accordance with the Italian specification, equivalent to the actual FeB500 as per EN 10027-1 [60]. Concrete cover is $2 \mathrm{~cm}$.

After curing, the specimens (Figure 1) were exposed to accelerated chlorides penetration, i.e. ponding cycles three week long: in the first week the upper surface of the concrete samples was wetted with a $5 \%$ sodium chloride solution, then for the next two weeks, samples were dried in laboratory.

Table 1. Tested organic substances.

\begin{tabular}{ccc}
\hline \multirow{2}{*}{ Amines } & Dimethylethanolamine (DMEA) & $\left(\mathrm{CH}_{3}\right)_{2}-\mathrm{N}-\left(\mathrm{OH} \mathrm{CH} \mathrm{CH}_{2} \mathrm{CH}_{2}\right)$ \\
\cline { 2 - 3 } & Triethylentetramine (TETA) & $\mathrm{NH}_{2}-\mathrm{CH}_{2} \mathrm{CH}_{2}-\left(\mathrm{NHCH}_{2} \mathrm{CH}_{2}\right)_{2}-\mathrm{NH}_{2}$ \\
\hline Carboxylates & Sodium benzoate & $\mathrm{C}_{6} \mathrm{H}_{5}-\mathrm{COOH}$ \\
\hline
\end{tabular}


Table 2. Concrete mixture proportion and properties.

\begin{tabular}{cccc}
\hline Cement type & \multicolumn{2}{c}{ CEM II A/L 42.5R } \\
Cement content & $\mathrm{kg} / \mathrm{m}^{3}$ & 320 & 310 \\
Water/Cement ratio & & 0.55 & 0.65 \\
Aggregate type & & limestone & limestone \\
Aggregate content & $\mathrm{kg} / \mathrm{m}^{3}$ & 1876 & 1812 \\
Plasticizer & $\mathrm{kg} / \mathrm{m}^{3}$ & 2 & 0.4 \\
Slump (EN 206) & $\mathrm{mm}$ & 210 & 210 \\
Curing time (>95\% RH) & days & 28 & 28 \\
28 days compressive strength & $\mathrm{MPa}$ & $46-47$ & $36-40$ \\
\hline
\end{tabular}

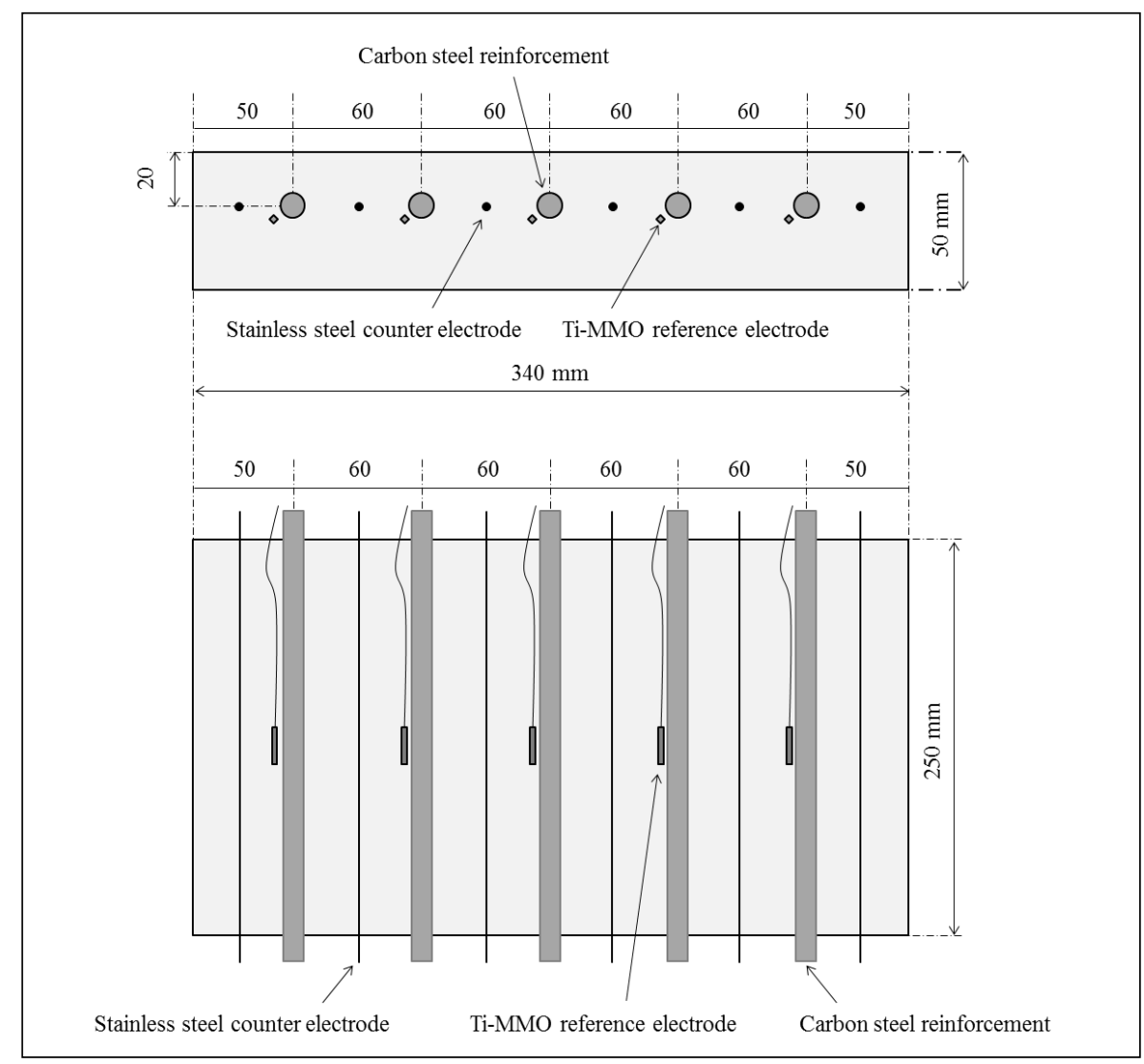

Figure 1. Reinforced concrete specimens geometry.

Corrosion was monitored by potential measurements with respect to a saturated calomel reference electrode (SCE, $+244 \mathrm{mV} \mathrm{SHE}$ ) placed on the wet concrete surface, and by corrosion rate evaluation. The latter has been obtained by means of linear polarization resistance technique, applying a potential scan rate of $10 \mathrm{mV} / \mathrm{min}$ in the range $\pm 10 \mathrm{mV}$ with respect to the free corrosion potential $[61,62]$. Mean value of corrosion rate, $i_{\text {corr }}$ $\left(\mathrm{mA} / \mathrm{m}^{2}\right)$ was evaluated by the Stern-Geary equation: 


$$
i_{\text {corr }}=C / R_{\mathrm{p}}
$$

where $R_{\mathrm{p}}$ is the polarization resistance $\left(\Omega \mathrm{m}^{2}\right)$ and $C$ is assumed equal to $26 \mathrm{mV}$ for active steel and $52 \mathrm{mV}$ for passive steel. For carbon steel, a current density of $1 \mathrm{~mA} / \mathrm{m}^{2}$ corresponds to a corrosion rate of $1.17 \mu \mathrm{m} / \mathrm{y}$. Since corrosion penetration lower than $1-$ $2 \mu \mathrm{m} / \mathrm{y}$ can be considered negligible [1], if the polarization resistance is higher than $20 \Omega \mathrm{m}^{2}$ corrosion rate can be considered negligible. On the other hand, when $R_{\mathrm{p}}$ is lower than $20 \Omega \mathrm{m}^{2}$ corrosion rate become significant.

In order to determine the chlorides profile, concrete cores $(30 \mathrm{~mm}$ in diameter) were extracted at different time. The cores were sliced (thickness about $10 \mathrm{~mm}$ ); each slice was milled and then dissolved in nitric acid. The total chlorides content was evaluated by potentiometric titration with $\mathrm{AgNO}_{3} 0.1 \mathrm{~mol} / \mathrm{L}$.

\section{Results and discussion}

The discussion of the results will be focused on the effect on the service life of reinforced concrete structure. According to Tuutti model [1], service life is divided into two phases: initiation, that correspond to the entry of aggressive species into concrete until reaching the rebars, and propagation, after depassivation of rebars. In the case of chloride induced corrosion, the most important effect is related to the delay of corrosion initiation, since corrosion propagation is very fast and corresponding time can be very short [1]. The effect on the corrosion initiation is further analysed to verify if the delay is due to a slower chloride transport into concrete or to an increase of the critical chloride threshold.

Only the results in concrete cast with w/c ratio 0.55 are presented. This concrete is closer to the requirements suggested by EN 206 standard [9] for chloride induced corrosion (w/c ratio 0.45 to 0.5 as a function of the exposure class). As expected, in concrete cast with w/c ratio 0.65 (more porous) the corrosion initiated in shorter time, due to the quicker arrival of chlorides to the rebar surface.

\section{Initiation of corrosion}

In Figure 2, some examples of the monitoring of corrosion potential and linear polarisation resistance are presented: at the beginning the values of corrosion potential are in between $-100 \mathrm{mV}$ and $-200 \mathrm{mV} \mathrm{SCE}$ and the polarization resistance in the range of $100 \Omega \mathrm{m}^{2}$, indicating passive conditions of the rebars. The initiation of corrosion is detected by a sharp decrease of corrosion potential, generally lower than $-300 \mathrm{mV} \mathrm{SCE}$; at the same time, or sometime later, a reduction of polarization resistance below $10-20 \Omega \mathrm{m}^{2}$ is observed. On few rebars polarization resistance and potential increase again in longer period, without reaching again the initial values. Corrosion initiation time of the rebars in the same experimental condition, that is presence, type and amount of corrosion inhibitors, can vary significantly (Figure 2). The reason of the scattering of the data can be due to both chloride transport, that can slightly vary in different specimens (due to heterogeneities of 
concrete) but mostly to the fact that localized corrosion is a stochastic phenomena and the initiation of corrosion can vary significantly in the same experimental conditions.
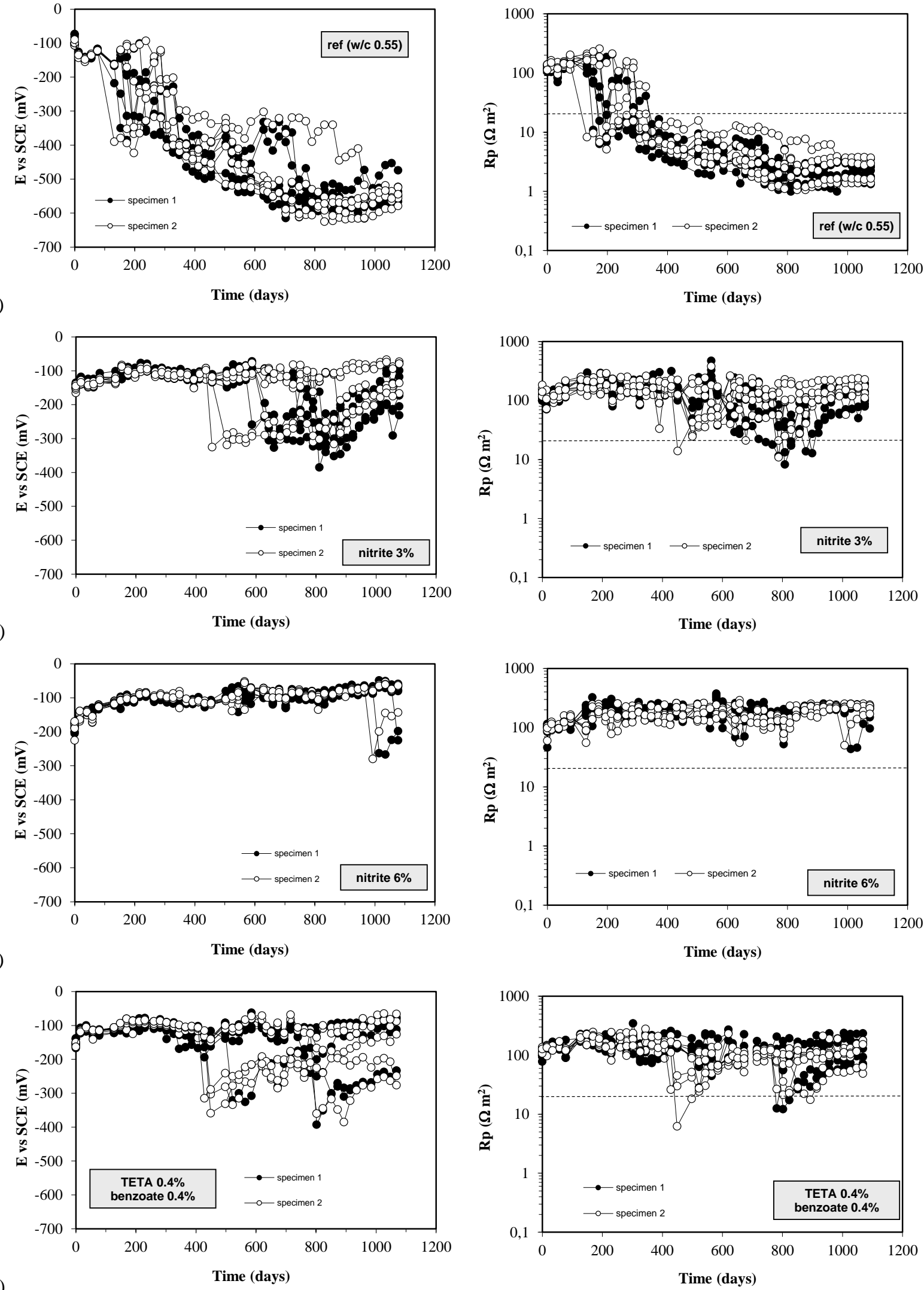

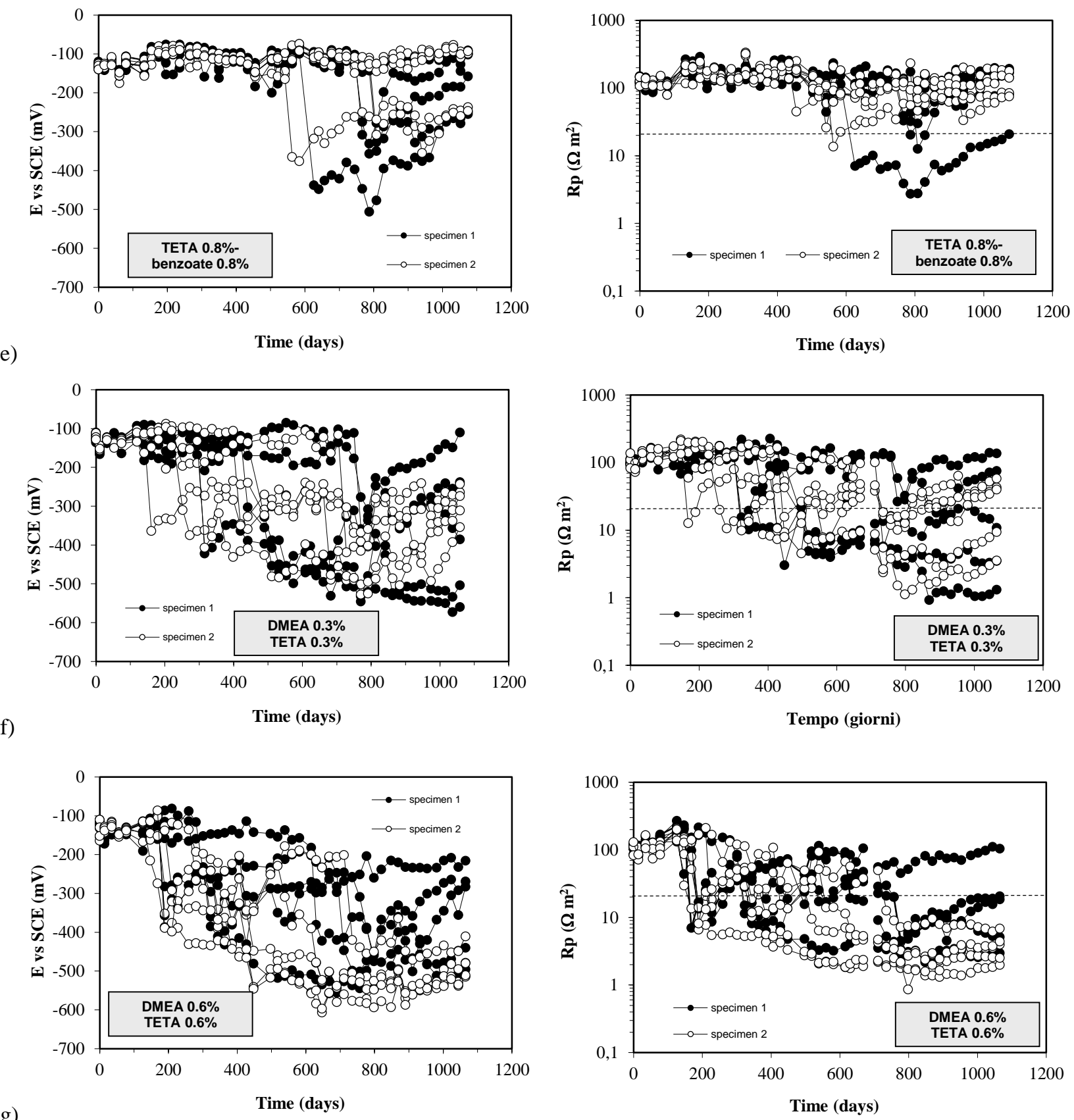

g)

Figure 2. Monitoring of corrosion potential (left) and linear polarization resistance (right) in concrete w/c 0.55: without inhibitors (a); $3 \%$ nitrite (b); $6 \%$ nitrite (c); $0.4 \%$ TETA-0.4\% benzoate (d); $0.8 \%$ TETA $-0.8 \%$ benzoate (e); $0.3 \%$ DMEA-0.3\% TETA (f); $0.6 \%$ DMEA$0.6 \%$ TETA $(\mathrm{g})$; the concentration of inhibitors in expressed vs. cement mass.

In concrete without inhibitors the initiation of corrosion occur for all the rebars within 300 days, whereas in concrete with nitrite $6 \%$, only 2 of 10 rebars suffer corrosion initiation at the end of the exposure (more than 1000 days). The best behavior among the binary mixtures is found for TETA $0.8 \%$ - benzoate $0.8 \%$ : corrosion occurs for 4 of 10 rebars, and the initiation of corrosion is detected after 500 days approximately for the first rebar. 
In Figure 3 the trend of corrosion potential and corrosion rate versus time is reported: for each condition (without and with different corrosion inhibitors), only the curve relative to the first rebar subjected to corrosion initiation is shown. The distribution of the cycle in which corrosion initiation was observed is reported in Figure 4. The most effective inhibitor is nitrite, confirming results obtained in the previous phase of the research when pure substances were analysed [55-57]. Only $20 \%$ of the rebars were corroded in presence of $6 \%$ nitrite by cement mass, and corrosion was strongly delayed: the first rebar corroded after 44 cycles, while in the reference concrete the first corrosion occurred just after the $5^{\text {th }}$ cycles (Table 3). The effect of the organic mixtures was not comparable to nitrite: the best performance was shown by TETA $(0.8 \%)$ with benzoate $(0.8 \%)$, with $40 \%$ of corroded rebars and a significant delay of corrosion initiation (Figure 4). The mixture DMEATETA is not effective: the corroded rebars are $90-100 \%$ and the delay of corrosion is not significant. Considering the scattering of the distribution, the lowest time for corrosion initiation were similar to rebars embedded in reference concrete, while the highest times were different and the behavior is slightly better for the mixture DMEA-TETA with respect to the absence of inhibitors.

Table 3. Performance of corrosion inhibitors in concrete w/c 0.55 .

\begin{tabular}{|c|c|c|c|}
\hline $\begin{array}{c}\text { Inhibitor } \\
(\% \text { of cement mass })\end{array}$ & $\begin{array}{l}\text { Corroded } \\
\text { rebars }\end{array}$ & $\begin{array}{c}\text { Initiation of corrosion } \\
\text { (minimum and maximum } \\
\text { cycle) }\end{array}$ & $\begin{array}{l}\text { Diffusion coefficient } \\
\qquad\left(10^{-12} \mathrm{~m}^{2} / \mathrm{s}\right)\end{array}$ \\
\hline Reference (no inhibitor) & $100 \%$ & $5-13$ & $10-20$ \\
\hline Nitrite $3 \%$ & $70 \%$ & $20-35$ & $7.2-16.3$ \\
\hline Nitrite $6 \%$ & $20 \%$ & $44-47$ & $4.7-15$ \\
\hline TETA $0.4 \%$ + benzoate $0.4 \%$ & $50 \%$ & $20-37$ & $5-16.7$ \\
\hline TETA $0.8 \%$ + benzoate $0.8 \%$ & $40 \%$ & $24-35$ & $9.1-13.3$ \\
\hline DMEA $0.3 \%$ + TETA $0.3 \%$ & $90 \%$ & $7-34$ & $6.1-25$ \\
\hline DMEA $0.6 \%$ + TETA $0.6 \%$ & $100 \%$ & $8-32$ & $10.5-16.5$ \\
\hline
\end{tabular}

\section{Chloride transport}

Chlorides transport in concrete is due to the presence of different mechanisms: mainly diffusion and capillary sorption [1]. Only for comparison purposes, experimental profiles were interpolated using an analytical solution of the second Fick's law of diffusion [1]:

$$
C_{x}=C_{S} \cdot\left(1-\operatorname{erf} \frac{x}{2 \sqrt{D_{a p p} t}}\right)
$$

where $C_{x}$ is the chloride content at the depth $x$ and $t$ is time, $C_{s}$ is the chlorides content at the concrete surface, assumed constant with time, and $D_{a p p}$ is the apparent chloride diffusion coefficient, assumed constant with time and space (i.e. concrete is homogeneous). 

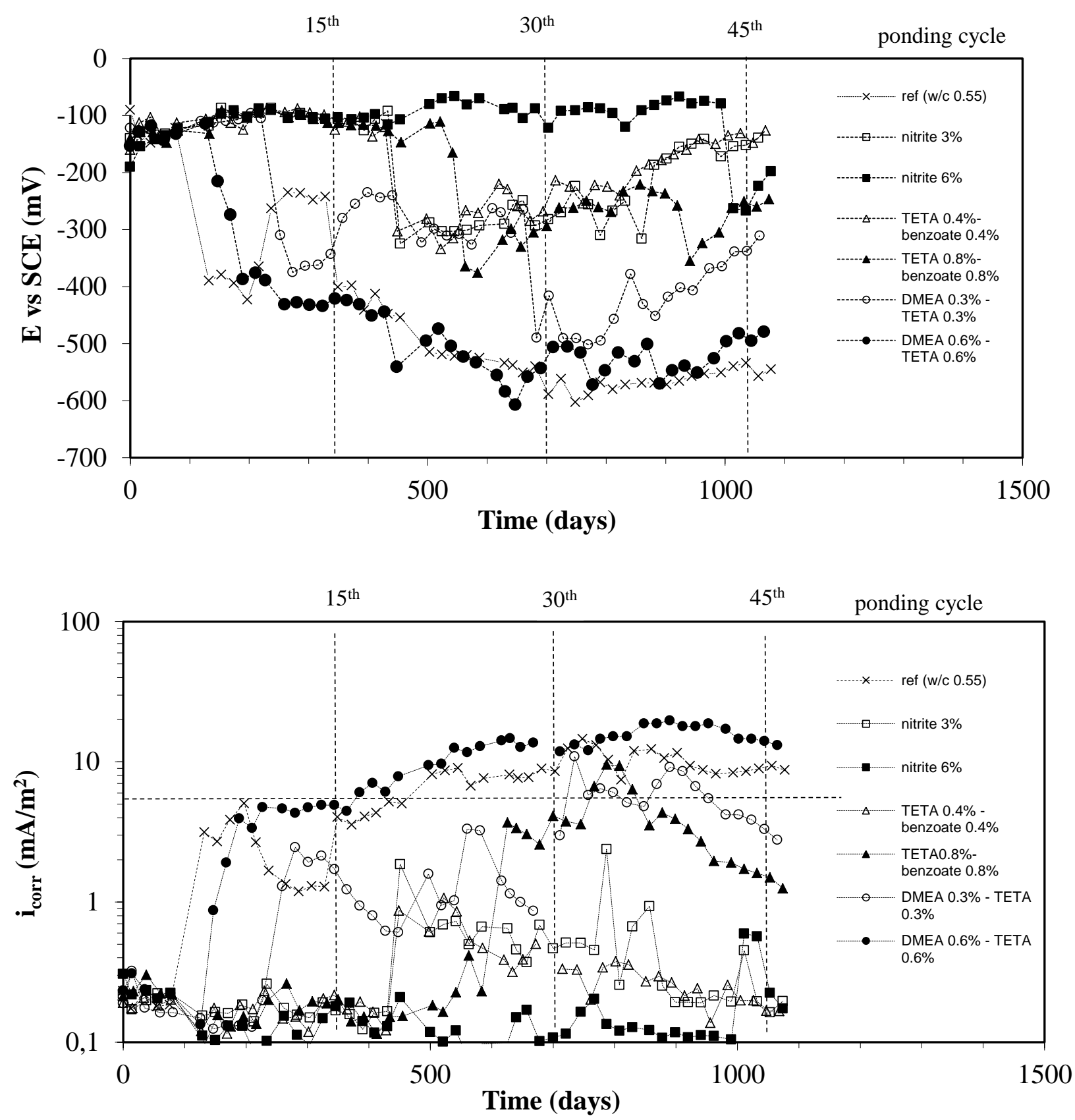

Figure 3. Monitoring of corrosion potential (top) and corrosion rate (bottom): for each inhibitor the rebar that first suffered corrosion is reported; the concentration of inhibitors is expressed $v s$. cement mass.

In concrete containing inhibitor TETA $0.4 \%$ - benzoate $0.4 \%$, chlorides content similar with respect to reference concrete is measured; the mixture TETA $0.8 \%$ - benzoate $0.8 \%$ and nitrite $6 \%$ decrease chloride content while the mixture DMEA-TETA and nitrite $3 \%$ increase chloride content. For comparison purposes, even if the w/c ratio is different, the results got in concrete with single substances are reported: in this case only TETA $1 \%$ 
was able to reduce chloride content, while DMEA increased chloride content. The data in Table 3 show that no significant and reproducible reduction of diffusion coefficient is noticed with respect to concrete without inhibitors.

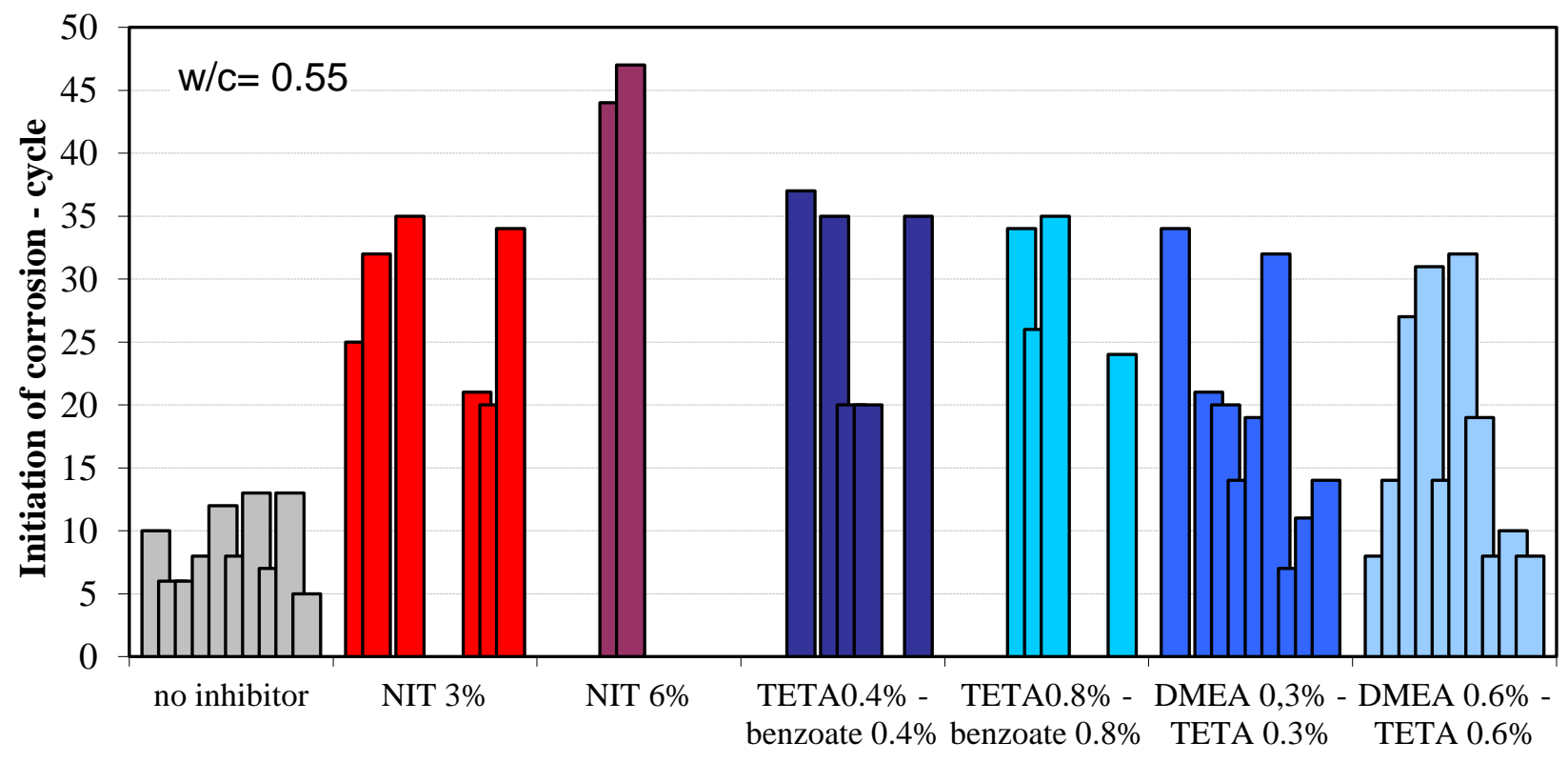

Figure 4. Cycle for initiation of corrosion on rebars in concrete without and with different corrosion inhibitors.
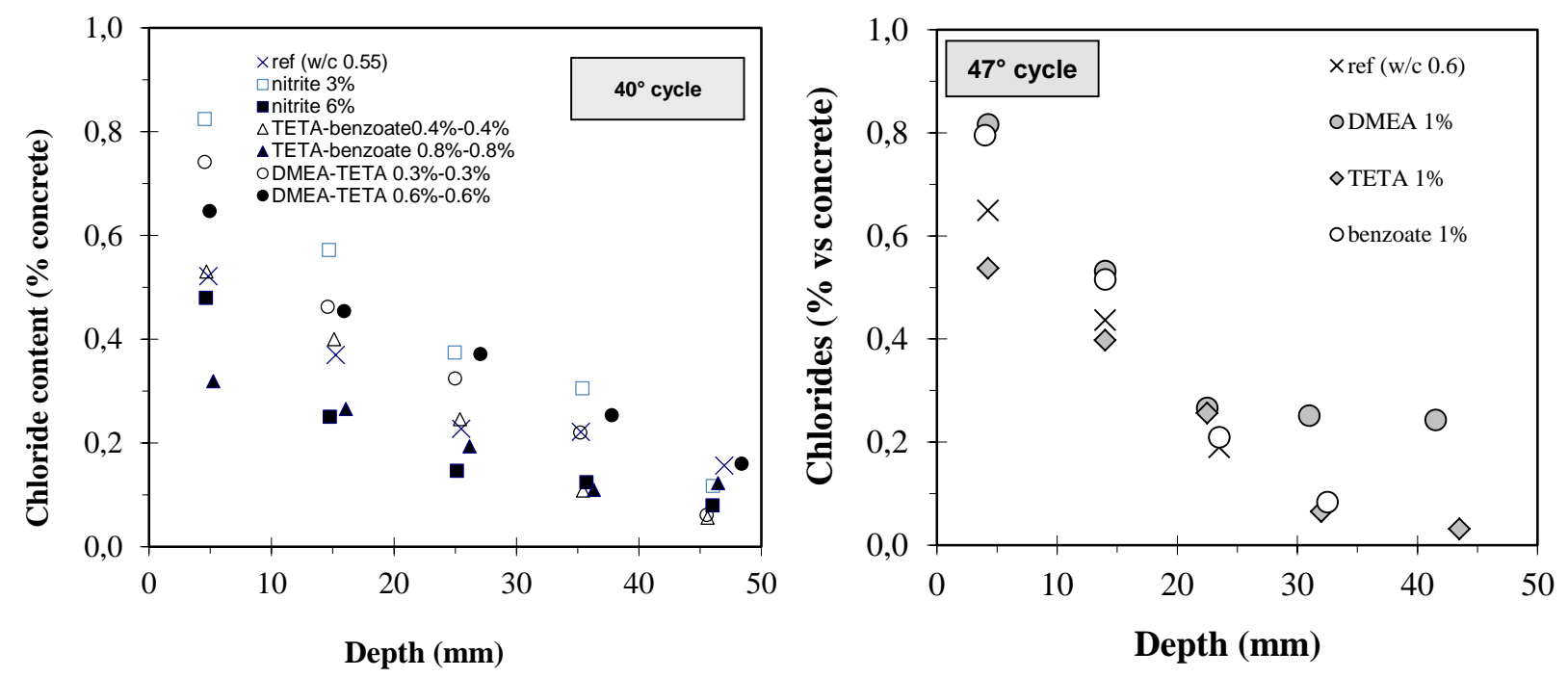

Figure 5. Chloride profile in concrete with different binary mixtures (left) and single substances (right); inhibitor concentration is expressed versus cement mass.

\section{Critical chloride content}

Critical chloride content was calculated from experimental data as the chloride content at the rebar level in correspondence with the cycle of corrosion initiation: the values are 
reported and compared to those got in previous phase of the research on pure substances $[55,57]$. The critical chloride content for carbon steel rebar in concrete without inhibitors is $1.2-1.8 \%$, higher than the usual range $0.4 \%$ to $1 \%$ by cement mass reported in literature [1]: this means that the data in Figure 6 have only to be considered for comparison purposes and not extrapolated to different experimental conditions. The critical chloride content is increased for most of the mixtures, even if the performance of nitrite ( 3 and $6 \%$ ) and pure TETA $(1 \%)$ overcome those of the binary mixtures, confirming the previous findings of the solution tests [58].

The overall expected effect of the experimental organic binary mixtures on service life of rebars in chloride contaminated concrete is moderate.

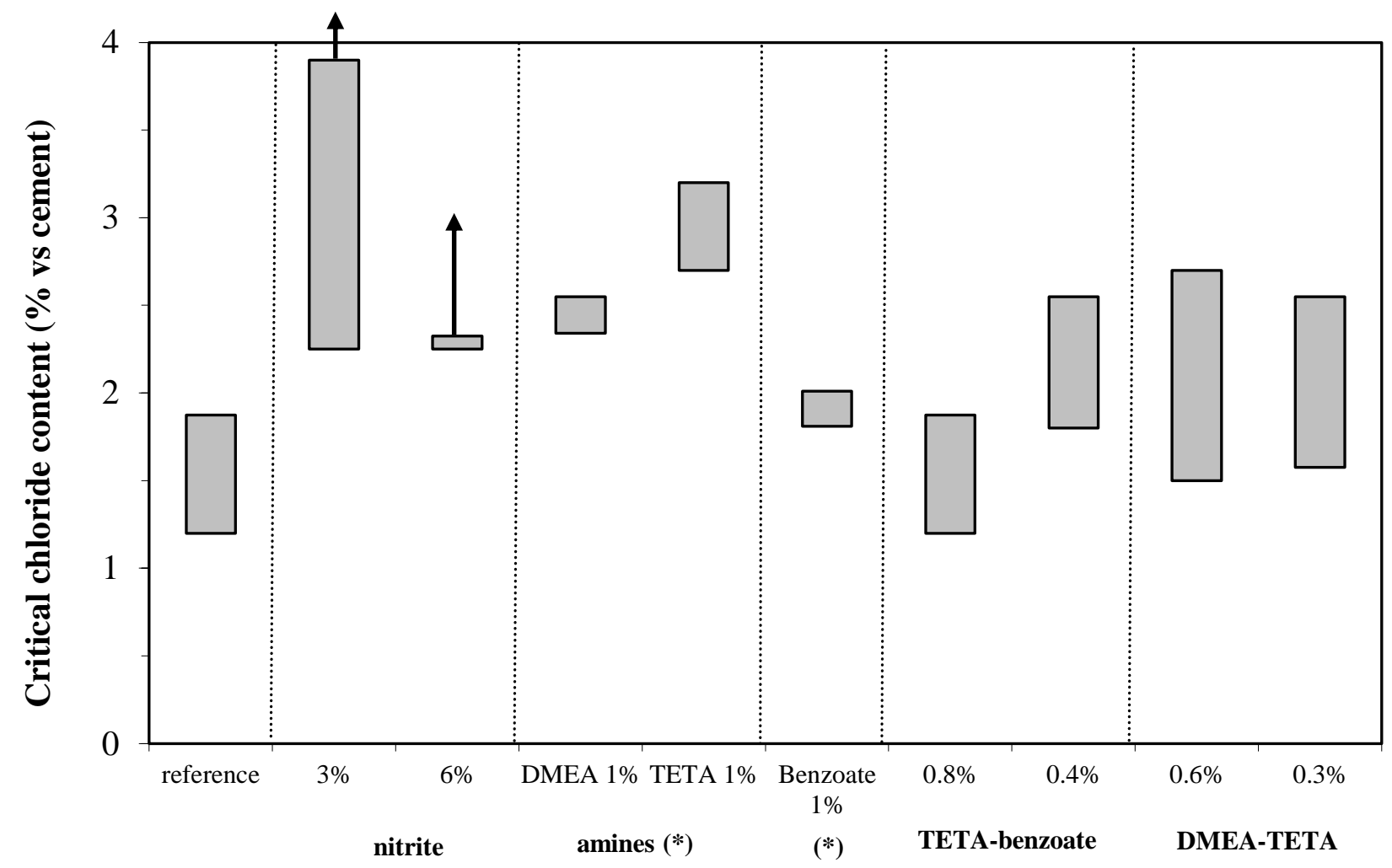

Figure 6. Critical chloride content in concrete for pure substances* [57] and binary mixture inhibitors (present work); concentration is reported versus cement mass.

\section{Conclusions}

The influence of binary mixtures of organic substances (amines and carboxylates) on the corrosion behavior of carbon steel in chloride contaminated concrete has been evaluated.

Some of the binary mixtures (TETA $0.8 \%$ and benzoate $0.8 \%$ by cement mass) are able to delay the initiation of corrosion and to reduce the number of corroded rebars. Nevertheless, the effect is less significant than the performance of nitrite and substance TETA alone. 
The delay of corrosion initiation is partly related to the reduction of the chloride transport into concrete (only for TETA $0.8 \%$ - benzoate $0.8 \%$ and nitrite $6 \%$ ) and partly to the increasing of the critical chloride content, i.e. the chloride content able to start corrosion. The overall expected effect on the service life of reinforced concrete structures is not significant.

\section{References}

1. L. Bertolini, B. Elsener, E. Redaelli, P. Pedeferri and R. Polder, Corrosion of steel in concrete: prevention, diagnosis, repair, 2013, Wiley, Weinheim.

2. D.A. Hausmann, Mater. Prot., 1967, 6, no. 11, 19-23.

3. V.K. Gouda, Brit. Corr. J., 1970, 5, no. 5, 198-203.

4. C.L. Page, Nature, $1975, \mathbf{2 5 8}$, no. 5535, 514-515.

5. P. Pedeferri, Constr. Build. Mater., 1996, 10, 391.

6. G.K. Glass and N.R. Buenfeld, Corros. Sci., 2000, 42, 923.

7. C. Alonso, M. Castellote and A. Andrade, Electrochim. Acta, 2002, 47, 3469.

8. U. Angst, B. Elsener, K.C. Larsen and Ø. Vennesland, Cem. Concr. Res., 2009, 39, 1122.

9. BS EN 206:2013, Concrete - Specification, Performance, Production and Conformity, Part 1.

10. EN 1992-1-1, Eurocode 2: design of concrete structures - Part 1-1: general rules and rules for buildings.

11. B. Elsener, Corrosion inhibitors for steel in concrete - State of the art report, EFC Publications, 2001, Number 35.

12. Yu.I. Kuznetsov, "Progress in the science of corrosion inhibitors", Int. J. Corros. Scale Inhib., 2015, 4, no. 1, 15-34. doi: 10.17675/2305-6894-2015-4-1-015-034

13. C.L. Page, In: Proceedings of the ninth European symposium on corrosion inhibitors, 2000, University of Ferrara (Italy), p. 261.

14. S.N. Alekseev, V.B. Ratinov, N.K. Rozental' and N.M. Kashurnikov, Ingibitory korrozii stali $v$ zhelezobetonnykh konstruktsiyakh (Steel corrosion inhibitors in reinforced concrete structures), Moscow, Stroiizdat, 1985 (in Russian).

15. N.S. Berke and T.G. Weil, in "Advances in Concrete Technology", Int. Conf. CANMET, Athen, Greece, 1992, pp. 899-924.

16. N.S. Berke and M.C. Hicks, Cem. Concr. Compos., 2004, 26, no. 3, 191-198.

17. C. Andrade, C. Alonso, M. Acha and B. Malric, Cem. Concr. Res., 1996, 26, 405-415.

18. V.T. Ngala, C.L. Page and M.M. Page, Corros. Sci., 2003, 45, 1523-1537.

19. F. Tittarelli, A. Mobili and T. Bellezze, IOP Conf. Ser.: Mater. Sci. Eng., 2017, 225, Issue 1, Article number 012106.

20. C.K. Nmai, S.A. Farrington and G.S. Bobrowsky, Concr. Int., 1992, 14, 45-51.

21. U. Mader, Concrete, 1999, 9, 215-232.

22. W. Morris and M. Vazquez, Cem. Concr. Res., 2002, 32, 259.

23. J. Tritthart, Cem. Concr. Res., 2003, 33, 829. 
24. F. Bolzoni, L. Coppola, S. Goidanich, L. Lazzari, M. Ormellese and MP. Pedeferri, Corros. Eng., Sci. Technol., 2004, 39, no. 3, 219.

25. M. Ormellese, M. Berra, F. Bolzoni and T. Pastore, Cem. Concr. Res., 2006, 36, 536.

26. F. Bolzoni, S. Goidanich, L. Lazzari and M. Ormellese, Corros. Eng., Sci. Technol., 2006, 41, no. 3, 212.

27. M. Ormellese, F. Bolzoni, S. Goidanich, MP. Pedeferri and A. Brenna, Corros. Eng., Sci. Technol., 2011, 46, no. 4, 334.

28. N.N. Andreev, D.S. Bulgakov, I.A. Gedvillo, A.S. Zhmakina and S.S. Vesely, Int. J. Corros. Scale Inhib., 2014, 3, no. 4, 238-245. doi: 10.17675/2305-6894-2014-3-4-238245

29. F. Bolzoni，A. Brenna，G. Fumagalli，S. Goidanich, L. Lazzari， M. Ormellese and MP. Pedeferri, Int. J. Corros. Scale Inhib., 2014, 3, no. 4, 254-278. doi: 10.17675/2305-6894-2014-3-4-254-278

30. N.N. Andreev, I.A. Gedvillo, A.S. Zhmakina, D.S. Bulgakov and S.S. Vesely, Int. J. Corros. Scale Inhib, 2016, 5, no. 4, 319-324. doi: 10.17675/2305-6894-2016-5-4-2

31. I.A. Gedvillo, A.S. Zhmakina, N.N. Andreev and S.S. Vesely, Int. J. Corros. Scale Inhib., 2017, 6, no. 1, 82-90. doi: 10.17675/2305-6894-2017-6-1-7

32. K.A. Alawi Al-Sodani, O.S. Baghabra Al-Amoudi, M. Maslehuddin and M. Shameem, Constr. Build. Mater., 2018, 163, 97-112.

33. C. Monticelli, A. Frignani and G. Trabanelli, Cem. Concr. Res., 2000, 30, 635.

34. E. Rakanta, T. Zafeiropoulou and G. Batis, Constr. Build. Mater., 2003, 44, 507.

35. F. Wombacher, U. Maeder, B. Marazzani, Cem. Concr. Compos., 2004, 26, 209.

36. N.N. Andreev and O.A. Goncharova, Prot. Met., 2004, 40, no. 3, 257-263 (Translated from Zashch. Met., 2004, 40, no. 3, 280).

37. G. Trabanelli, C. Monticelli, V. Grassi and A. Frignani, Cem. Concr. Res., 2005, 35, 1804.

38. L. Mechmeche, L. Dhouibi, M. Ben Ouezdou, E. Triki and F. Zucchi, Cem. Concr. Compos., 2007, 29, 365.

39. T.A. Soylev and M.G. Richardson, Constr. Build. Mater., 2008, 22, 609.

40. E.V. Starovoitova, I.A. Gedvillo, A.S. Zhmakina, and N.N. Andreev, Prot. Met. Phys. Chem. Surf., 2010, 46, no. 7, 793. (Original Russian text published in Korroziya: Materialy, Zashchita, 2009, no. 6, 30).

41. C. Monticelli, A. Frignani, A. Balbo and F. Zucchi, Mater. Corros., 2011, 62, 178.

42. T. Pastore, M. Cabrini, L. Coppola, S. Lorenzi, P. Marcassoli and A. Buoso, Mater. Corros., 2011, 62, no. 2, 187.

43. S.-H. Tae, Constr. Build. Mater., 2012, 35, 270.

44. M. Criado, C. Monticelli, S. Fajardo, D. Gelli, V. Grassi and J.M. Bastidas, Constr. Build. Mater., 2012, 35, 30.

45. M. Cabrini, S. Lorenzi and T. Pastore, Metall. Ital., 2013, 105, no. 7-8, 21-31.

46. M. Cabrini, S. Lorenzi and T. Pastore, Electrochim. Acta, 2014, 124, 156.

47. F.L. Fei, J. Hu, J.X. Wei, Q. Yu and Z. Chen, Constr. Build. Mater., 2014, 70, 45. 
48. J.O. Okeniyi, O.A. Omotosho, O.O. Ajayi and C.A. Loto, Constr. Build. Mater., 2014, 50, 448.

49. M. Cabrini, F. Fontana, S. Lorenzi, T. Pastore and S. Pellegrini, J. Chem., 2015, art. no. 521507. doi: $10.1155 / 2015 / 521507$

50. H.S. Ryu, J.K. Singh, H.M. Yang, H.S. Lee and M.A. Ismail, Constr. Build. Mater., 2016, 114, 223.

51. W. Martinez, A. Torres, R. Hernández, E. Alonso, I. Mendoza and I. Martinez, AntiCorros. Meth. Mater., 2016, 63, 65.

52. H. Bensabra, N. Azzouz, O. Aaboubi and J.P. Chopart, Metall. Res. Technol., 2016, 113, 102.

53. Yu.I. Kuznetsov, Int. J. Corros. Scale Inhib., 2017, 6, no. 3, 209. doi: 10.17675/23056894-2017-6-3-1

54. Y. Wang and Y. Zuo, Corros. Sci., 2017, 118, 24.

55. M. Ormellese, F. Bolzoni, L. Lazzari and P. Pedeferri, Mater. Corros., 2008, 59, 98.

56. M. Ormellese, L. Lazzari, S. Goidanich, G. Fumagalli and A. Brenna, Corros. Sci., 2009, 51, 2959.

57. M. Ormellese, F. Bolzoni, L. Lazzari, A. Brenna and M. Pedeferri, Mater. Corros., 2011, 62, no. 2, 170.

58. A. Brenna, F. Bolzoni, M. Pedeferri and M. Ormellese, Int. J. Corros. Scale Inhib., 2017, 6, no. 1, 59-70. doi: 10.17675/2305-6894-2017-6-1-5

59. CEN EN 197/1: Standard, Cement - Part 1: composition, specifications and conformity criteria for common cements, 2000

60. CEN EN 10027-1 Designation systems for steels Part 1: Steel names, 2005.

61. M. Stern and A.L. Geary, J. Electrochem. Soc., 1957, 104, 56.

62. C. Andrade and J.A. Gonzalez, Werkst. Korros., 1978, 29, 516. 